\title{
Lip and Oral Cavity Cancer Pathologic Primary Tumor TNM Finding v8
}

National Cancer Institute

\section{Source}

National Cancer Institute. Lip and Oral Cavity Cancer Pathologic Primary Tumor TNM

Finding v8. NCI Thesaurus. Code C132691.

A pathologic finding about one or more characteristics of lip and oral cavity cancer,

following the rules of the TNM AJCC v8 classification system as they pertain to staging of the primary tumor. 